\title{
BIOTEHNOLOGII AVANSATE DE OBTIINERE A PREPARATULUI BIOLOGIC ÎN SCOPUL COMBATERII DĂUNĂTORILOR
}

\author{
Stingaci A., Volosciuc L. \\ Institute of Genetics, Physiology and Plant Protection, 2002,Chisinau, Padurii str.26/1, \\ e-mail: aurelia.stingaci@gmail.com,
}

\begin{abstract}
Biopesticides have also attracted great interest in the international research community, with a significant increase in the number of publications devoted to the subject. At Institute of Genetics, Physiology and Plant Protection are prepared the bioinsecticides for use in Republic Moldova, mostly for the control In order to reduce the population of insect it is recommended utilization inoffensive preparations baculoviruses highly-pathogenic for the leaf-champing vermis of the H.cunea,were selected from the insect natural populations which is an efficient preparation for combating this pest in agricultural, onamental and forest biocenosis. This study aimed to highlight new agents for biological control of pest..
\end{abstract}

Key words: Hyphantria cunea Drury, biopesticides, baculovirus

\section{Introducere}

Actualmente, vânzările de biopesticide pe piața mondială constituie anual circa 396 mil. \$/an, aflându-se în continuă ascensiune. Țările Americii de Nord rămân lideri în producerea şi realizarea biopesticidelor pe piața mondială. Țările Europene treptat devin cei mai importante consumatori, ca urmare a exigenței în respectarea regulamentului de utilizare a pesticidelor şi sporirea cererii de produse ecologice. Statele Unite ale Americii, China, Rusia, India sunt principalii producători de pesticide microbiene. Din cele 281 de biopesticide disponibile în prezent pe piață mondială, 30 \% au la bază diferite tulpini bacteriene, 38,1\% constituie diferite specii de insecte parazite sau prădătoare, $15,7 \%$ - nematozi, 4,27\% ciupercile, $2,85 \%$ - viruşi şi $2,14 \%$ - protozoarele [4, 3, 2].

Organismele dăunătoare din diferite motive pătrund în ecosistemele agricole și forestiere şi se pot extinde vertiginos pe teritorii mari concretizat şi prin aceea că populaţiile 
de insecte dăunătoare depășesc frecvent nivelele de densitate, producând gradații și dezechilibru ecologic. Dintre toate speciile de defoliatori, Omida-păroasă-a-dudului (Hyphantria cunea Drury) s-a dovedit a avea cel mai mare potențial de dăunare de-a lungul timpului, producând multe gradații de tip eruptiv-pulsator cu ciclicitate variabilă, în funcție de zona fitogeografică, condițile și caracteristicile ecosistemelor [1].

Gradul înalt de nocivitate a $H$. cunea în condițiile Republicii Moldova este determinat şi de capacitatea de aşi forma rezistenţa un spectru larg de pesticide. Actualitatea şi complexitatea problemei, metodele şi căile de sporire a eficienței preparatelor ecologice necesită studierea în continuare. Este necesar de a depune efort continuu pentru a satisface cererea mediului de afaceri şi a economiei naționale în preparate ecologice de control al insectelor dăunătoare. Controlul biologic reprezintă una din abordările de succes în gestionarea durabilă a insectelor dăunătoare.

Actualitatea şi complexitatea problemei, metodele şi căile de creştere a eficienţei potenţialului a preparatelor ecologice trebuie studiate în continuare. Toate acestea aspecte, situaţii şi probleme nesoluţionate, luate în ansamblu, au dictat alegerea temei.

\section{Materiale și metode}

În experiențele de laborator și câmp au fost aplicate ambele genuri de baculovirusuri (Baculoviridae): Nucleopolyhedrovirus şi Granulovirus [5]. Pentru cercetare au fost folosite atât tulpinile virusul poliedrozei nucleare, cât și cele ale virusului granulozei. Pentru experiențe au fost folosite scheme, bazate pe recomandările metodice existente.

Purificarea incluziunilor virale. În procesul de apreciere a activităţii biologice a baculovirusurilor este absolut necesară purificarea lor. Procesul de purificare este determinat de proprietăţile hidrodinamice şi fizico-chimice ale incluziunilor. La fazele iniţiale purificarea VPN şi VG nu se deosebesc esenţial.

Titrarea baculovirusurilor. Pentru determinarea concentraţiei baculovirusurilor se folosesc diverse metode, îndeosebi, microscopia electronică şi optică. Titrarea se efectuează cu ajutorul camerei Goreaiev sau în preparatele fixate şi colorate. Titrarea VG s-a efectuat cu ajutorul microscopului electronic EM - 200, EMB - 100, folosind metodele de contrastare negativă sau pozitivă $[2,7]$.

Determinarea activităţii biologice a preparatului. Au fost elaborate mai multe metode de determinare a activităţii biologice a baculovirusurilor. La faza iniţială, suspensia virală s-a titrat, determinând concentraţia ei. Apoi s-a pregătit o serie de diluţii succesive cu care s-a infectat larvele de vârsta a doua (e raţional de-a folosi câte 40 larve de aceiaşi stare fiziologică). În a treia zi s-a determinat mortalitatea larvelor pe variante şi s-a întocmit graficul dependenţei ,doză-efect”. Pentru aceasta s-a aplicat metoda analizei probelor. S-a efectuat calcule suplimentare, care permit transformarea axelor de coordonate pentru a obţine dependenţa „doza - efect” în formă de linie dreaptă, și nu de curbă exponenţială. Construirea graficului a permis determinarea logaritmului dozei suspensiei virale care asigură moartea a $50 \%$ din larvele experimentale. Cunoscând concentraţia virusului şi volumul suspensiei virale s-a determinat ușor concentraţia letală $\left(\mathrm{CL}_{50}\right)$.

Obținerea biomasei virale. Dezvoltarea unor tehnologii viabile necesită selecţia unei tulpini virulente a baculoviruşilor la specia $H$. cunea, fiind foarte important să fie selecţionată tulpina cea mai activă pentru multiplicare, înregistrare şi folosire. A fost aleasă această metodă datorită aproprierii de condițiile de câmp, ingerarea de frunze cu baculovirusuri fiind calea obişnuită de infestare a larvelor în natură. Baculovirusurile au fost izolate din cadavrele larvelor afectate şi puse în evidenţă cu ajutorul tehnicilor de microscopie electronică. În cercetările realizate s-au folosite baculovirusuri din trei surse:1.VG izolat din larve de $H$. 
cunea colectate în România, Ocolul silvic Snagov; 2.VG izolat din larve de H. cunea provenite din Republica Moldova, Rezervaţia științifică „Codrii”; 3.VPN izolat din larve de H. cunea provenite din Republica Moldova, Hruşova (Criuleni). S-a obţinut forma vastă a preparatelor baculovirale. Datele estimate au fost procesate în confomitate cu pachetul Software Microsoft [6].

\section{Rezultate și discuții}

Considerăm util a prezenta înainte de a trece la expunerea rezultatelor cercetărilor care au stat la baza elaborării schemei tehnologice de obţinere a preparatului viral, rezultatele unor cercetări, în cadrul cărora a fost studiată selecţia unor tulpini virulente a baculovirusurilor la specia $H$. cunea, fiind foarte important să devină selecţionarea pentru reproducerea activă, înregistrarea şi folosirea, în calitate de agent biologic activ. În cercetările noastre am folosit baculovirusuri din trei surse (Tabelul 1).

Tabelul 1. Izolarea și identificarea a tulpinilor de baculovirusuri la $H$. cunea

\begin{tabular}{|c|c|c|c|c|c|c|c|}
\hline \multirow[t]{2}{*}{ Nr. } & \multirow{2}{*}{$\begin{array}{r}\text { Specia } \\
\text { dăunătorului }\end{array}$} & \multirow{2}{*}{$\begin{array}{l}\text { Locul } \\
\text { colectării }\end{array}$} & \multicolumn{4}{|c|}{ Agenți patogeni identificați } & \multirow[t]{2}{*}{ Aplicarea } \\
\hline & & & $\begin{array}{l}\text { Baculo- } \\
\text { virusuri }\end{array}$ & $\begin{array}{l}\text { Bac- } \\
\text { terii }\end{array}$ & $\begin{array}{l}\text { Ciu- } \\
\text { perci }\end{array}$ & $\begin{array}{l}\text { Micro- } \\
\text { sporidii }\end{array}$ & \\
\hline 1 & $\begin{array}{c}\text { Hyphantria cunea } \\
\text { Drury }\end{array}$ & Romania & VG & + & + & - & $\begin{array}{l}\text { Virin-ABB-3, } \\
\text { Cercetare, } \\
\text { schimb }\end{array}$ \\
\hline 2 & $\begin{array}{c}\text { Hyphantria cunea } \\
\text { Drury }\end{array}$ & $\begin{array}{l}\text { Republica } \\
\text { Moldova }\end{array}$ & VG & + & + & - & $\begin{array}{l}\text { Virin-ABB-3, } \\
\text { Cercetare, } \\
\text { schimb }\end{array}$ \\
\hline 3 & $\begin{array}{c}\text { Hyphantria cunea } \\
\text { Drury }\end{array}$ & $\begin{array}{l}\text { Republica } \\
\text { Moldova }\end{array}$ & VPN & + & + & - & $\begin{array}{l}\text { Virin-ABB-3, } \\
\text { Cercetare, } \\
\text { schimb }\end{array}$ \\
\hline
\end{tabular}

Materialul biologic obţinut a fost analizat la microscopul optic pentru depistarea baculovirusurilor. Femelele moarte de baculovirusuri, bănuite că moartea s-au datorat unui proces patologic, s-au tratat pe suprafaţa corpului cu alcool etilic (70\%) şi ulterior au fost selectate pentru analiza histologică. Apoi s-a luat o porţiune din ţesut care şi s-a decupat cu ajutorul bisturiului steril din ţesutul bolnav, care s-a fărâmiţat într-un major steril şi s-a introdus în 2-3 ml apă sterilă, obținând suspensia cu care a fost utilizată pentru infectarea larvelor.

Dăunătorul atacă în Europa Centrală mai mult de 234 specii de arbori şi arbuşti, plante erbacee şi pomi fructiferi. În țara de origine, America de Nord, $H$. cunea frecvent atacă nucul american (Nuta) şi arţarul (Acer negundo). În Republica Moldova aceste specii sunt considerate ca plante indicatoare pentru semnalarea acestui dăunător. Au fost evidențiate 124 specii de plante gazdă, care pot servi ca bază nutritivă pentru larvele de $H$. cunea în condițiile agroclimaterice ale Republicii Moldova. Totodată s-a constatat, că speciile de arţar (Acer negundo) şi dud (Morus nigra) sunt cele mai preferabile în calitate de substrat trofic pentru obținerea biomasei baculovirale [1].

S-a constatat că numărul adulţilor ai speciei $H$. cunea, căpturaţi în capcana feromonală cu lumină, colectaţi în decursul anilor 2010-2013, a atins 187 de exemplare, zborul pentru adulţi a fost înregistrat la 21 exemplare în 2013 şi 54 exemplare în 2012 (Figura 1). 


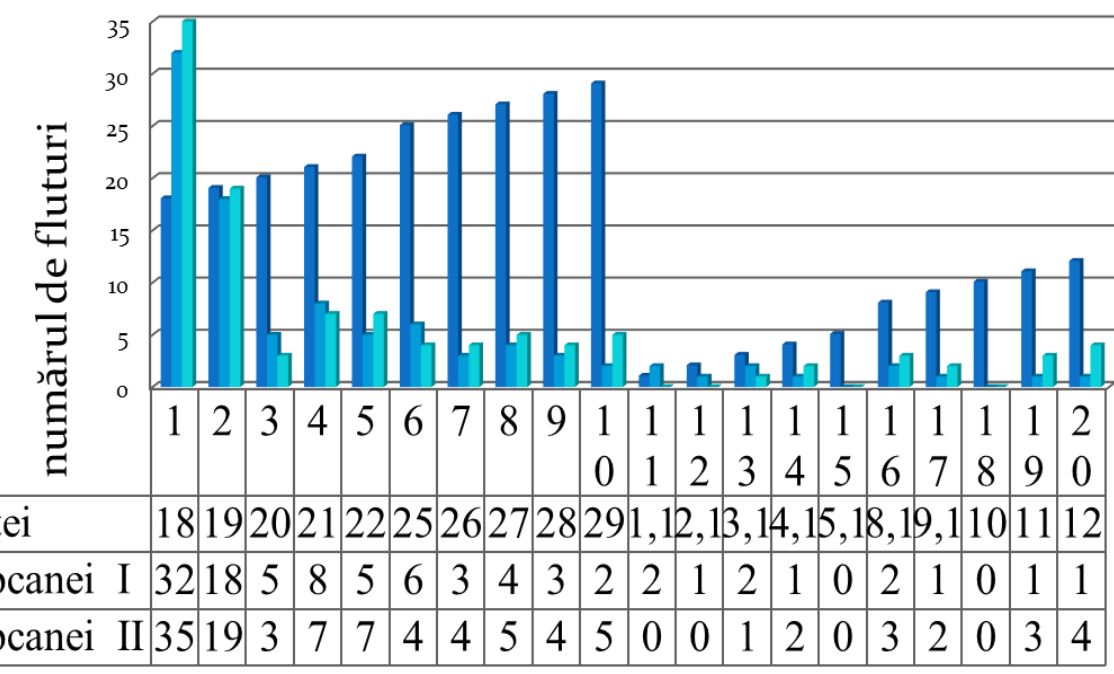

Fig. 1. Dinamica numărului de adulţi ai speciei $H$. cunea, căpturaţi în capcana feromonală cu lumină, 2010-2013

Ca urmare a studiului acțiunii prolificității și modului de depunere a pontei de oua a $H$. cunea au fost efectuate observații zilnice asupra depunerii pontei, locul și modul de depunere a pontei, numărul de ponte depuse. Cercetările efectuate au demonstrat, că copulaţia adulţ̧ilor poate avea loc imediat după emergenţa din crisalidă. Starea diapauzei facultative este cunoscută pentru multe specii de insecte, inclusiv şi pentru H. cunea. Cauzele diapauzei doar a unor indivizi din aceeaşi populaţie nu au fost încă elucidate (Figura 2, 3).

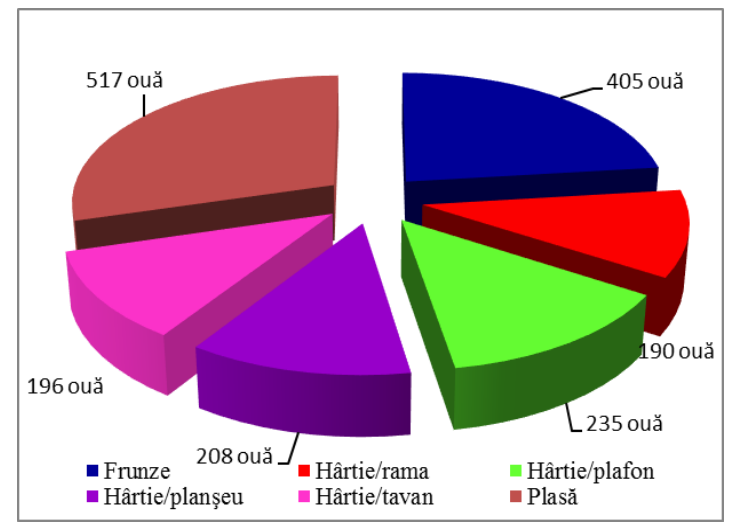

Fig. 2. Prolificitatea medie în funcţie de ovipoziţie a unei femele colectate în natură şi comportamentul de ovipoziţie în condiţii de laborator

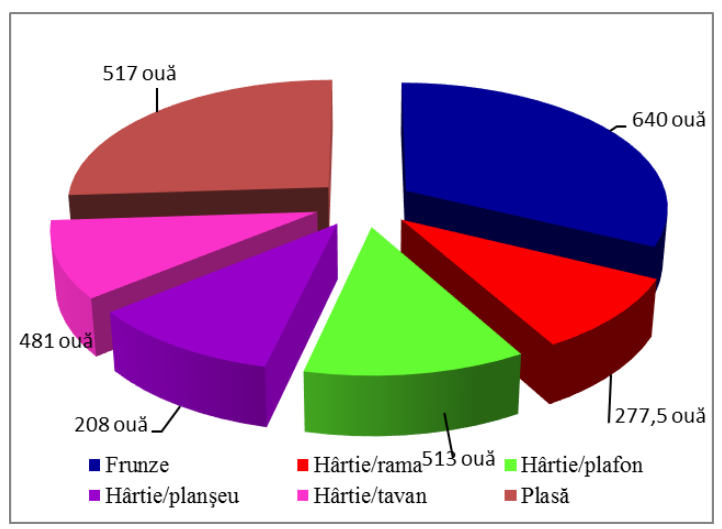

Fig. 3. Prolificitatea medie în funcţie de ovipoziţie la femelele speciei $H$. cunea crescute pe mediu artificial în condiţii de laborator

S-a demonstrat, că aceasta este o adaptare la condiţiile nefavorabile. Ouăle sterile se disting prin culoarea galben-portocalie. Pontele depuse în condiţii de laborator de femelele $H$. cunea, colectate în natură, conţin de la 208 până la 1661 ouă, media fiind - 544,3. Numărul de ponte depuse variază de la 1 până la maximum 2. Ovipoziţia a avut o perioadă cuprinsă între două şi şase zile, cu media de 2,1 zile. În condiţii naturale copularea se desfăşoară numai în 
zorii zilei, la răsăritul soarelui. Femelele căpturate își depun pontele în perioada depusă între 2-6 zile. Dacă aceste femele ulterior sunt fecundate, acestea pot depune ouă fertile. Ovipoziţia urmează imediat după fecundare şi poate să dureze între 8 ore şi 5 zile, iar mai mult de $50 \%$ din ouă sunt depuse în prima zi. Femela depune ponta de ouă pe suprafața inferioară a frunzelor de dimensiuni mici într-un singur strat. Oul rotund, galben-verzui sau galben-auriu, cu nuanţă albastră cu diametrul de 0,5-0,7 mm, pe măsură ce embrionul se dezvoltă, devine gri murdar. Femelele plasează ouăle prin grămezi de un singur strat cu dimensiunea de 1-2 $\mathrm{cm}^{2}$, câte 100-600 bucăţi fiecare. Prolificitatea medie a unei femele în laborator este de 720,7 de ouă.

Păstrarea numărului optim reprezintă unul dintre mecanismele necesare pentru menţinerea homeostaziei populaţiei. În entomologie numărul indivizilor în primul rând are o valoare economică, ca un indice care corespunde obiectivelor programului de creştere. Şi acest lucru este valabil atât pentru programele de creştere ale producătorilor de materie primă şi produse alimentare, cât şi pentru programele de înmulțirea a insectelor.

\section{Concluzii}

Bioinsectecidele constituie aproximativ 5\% din cantitatea de pesticide vândute pe plan mondial. Obiectivele principale ale agriculturii mondiale constituie elaborarea unor soluții alternative de control a dăunătorilor așa cum ar fi bioinsecticidele pe bază de baculovirusuri. În acest context este foarte actuală problema elaborării unor mijloace principale noi de-a integra un Baculovirus apărut în mod natural într-o populaţie de insecte dăunătoare, într-un biopreparat stabil, sigur şi eficient în controlul speciei. Din punct de vedere economic sunt rentabile deoarece pot declanşa epidemii virale, care se menţin timp de mai mulţi ani de zile. Baculoviruşii reprezintă un interes ştiinţific şi practic în calitate de mijloace de protecţie efective şi ecologic inoffensive a insectelor dăunătoare. Numărul maxim posibil de generaţii în condițiile de laborator depinde de menținerea parametrilor optimi de vârstă şi sex a populației artificiale. Optimizarea permanentă a populației de insecte poate duce la rezultate imprevizibile şi nedorite. Până în prezent aceste întrebări nu sunt pe deplin elucidate.

\section{Bibliografie}

1. Stîngaci, A. Biologia și combaterea microbiologică a Omizii-păroase-a-dudului $(H$. cunea în Republica Moldova. In: Simpozionul științific internațional "Horticultura modernărealizări şi perspective" dedicat a 85 de ani de la fondarea Universității Agrare de Stat din Moldova, Chişinău, 2018, pp. 633-637. ISBN 978-9975-64-296-5 (p. 180-186).

2. Voloşciuc, L.T. Probleme ecologice în agricultură. În: Chişinău: Bons Offices, 2009. 264 p. ISBN 978-9975-9774-5-6.

3. Agrow Biopesticides. Biologicals 2018, an analisis of corporate, product and rfegulatory news. Agribusiness Intelligence, [online]. Informa UK Ltd., Christchurch Court, London EC1A 7AZ, UK, 2018 [citat 21.01.2019]. ISNN 0268-313X. Disponibil: http://www.agrow.com.

4. Biopesticides Market by Active Ingredient (Microbials \& Biorationals), by Types (Bioinsecticides, Biofungicides, Bionematicides \& Bioherbicides), by Application, by Formulation, by Crop Type \& by Geography - Global trends \& forecasts to 2019. In: Markets and Markets Inc., 2015 [citat 21.08.2018]. Disponibil: http://www.marketreportshub.com.

5. Theilmann, D.A., Blissard, G.W. Baculoviruses: molecular biology of nucleopolyhedroviruses. In: Encyclopedia of Virology, 3rd edn, Oxford, Academic Press, 2008, pp. 254-265. ISBN 13: 978-0123739353. 
6. Чухрий, М.Г. Биология бакуловирусов и вирусов цчитоплазматического полиедроза. Кишинёв: Штиинца, 1988. 237 с. 